\title{
An In vitro Experiment on Bone Growth and Differentiation in Human Bone Osteosarcoma Cells (MG-63): Impact of Biofield Energy Treated Vitamin $\mathrm{D}_{3}$
}

\author{
Haddon Norman Salt ${ }^{1}$, Mahendra Kumar Trivedi ${ }^{1}$, Alice Branton ${ }^{1}$, Dahryn Trivedi ${ }^{1}$, Gopal Nayak ${ }^{1}$, \\ Sambhu Charan Mondal ${ }^{2}$, Snehasis Jana, ${ }^{2, *}$ \\ ${ }^{1}$ Trivedi Global, Inc., Henderson, USA \\ ${ }^{2}$ Trivedi Science Research Laboratory Pvt. Ltd., Bhopal, India
}

Email address:

publication@trivedisrl.com(S. Jana)

${ }^{*}$ Corresponding author

\section{To cite this article:}

Haddon Norman Salt, Mahendra Kumar Trivedi, Alice Branton, Dahryn Trivedi, Gopal Nayak, Sambhu Charan Mondal, Snehasis Jana. An In vitro Experiment on Bone Growth and Differentiation in Human Bone Osteosarcoma Cells (MG-63): Impact of Biofield Energy Treated Vitamin $\mathrm{D}_{3}$. International Journal of Biochemistry, Biophysics \& Molecular Biology. Vol. 3, No. 1, 2018, pp. 10-18. doi: 10.11648/j.ijbbmb.20180301.12

Received: February 6, 2018; Accepted: February 12, 2018; Published: April 19, 2018

\begin{abstract}
The study was aimed to evaluate the effect of Biofield Energy Treated vitamin $\mathrm{D}_{3}$ and DMEM medium on bone health parameters such as ALP, collagen, and bone mineralization in human bone osteosarcoma cells (MG-63). The test items (TI), were divided into two parts. One part of each sample received the Consciousness Energy Healing Treatment by Haddon Norman Salt and those samples were labeled as the Biofield Energy Treated (BT) samples, while the other parts of each sample were denoted as the untreated test items (UT). The cell viability by MTT assay data showed that the test samples were found as safe in the tested concentrations. The level of ALP was significantly increased by $73.24 \%$ and $85.41 \%$ in the UT-DMEM + BTTest TI and BT-DMEM + BT-TI, respectively at $10 \mu \mathrm{g} / \mathrm{mL}$ compared to the UT-DMEM + UT-TI group. Further, ALP level was significantly elevated by $76.71 \%$ in the BT-DMEM + UT-TI group at $0.1 \mu \mathrm{g} / \mathrm{mL}$ compared to the untreated. Collagen was significantly increased by $77 \%, 113.53 \%$, and $98.00 \%$ in the UT-DMEM + BT-TI, BT-DMEM + UT-TI, and BT-DMEM + BT$\mathrm{TI}$, respectively at $50 \mu \mathrm{g} / \mathrm{mL}$ compared to the untreated. Further, the collagen level was significantly increased by $128.05 \%$ and $132.10 \%$ in the UT-DMEM + BT-TI and BT-DMEM + BT-TI groups, respectively at $100 \mu \mathrm{g} / \mathrm{mL}$; while increased by $76.31 \%$ in the BT-DMEM + UT-TI at $10 \mu \mathrm{g} / \mathrm{mL}$ compared to the untreated. Besides, the percent of bone mineralization was distinctly increased by $82.43 \%, 158.97 \%$, and $52.95 \%$ at $0.1 \mu \mathrm{g} / \mathrm{mL}$ in the UT-DMEM + BT-TI, BT-DMEM + UT-TI, and BT-DMEM + BT-TI groups, respectively compared to the untreated. The percent of bone mineralization was significantly increased by $118.41 \%, 197.42 \%$, and $116.94 \%$ in the UT-DMEM + BT-TI, BT-DMEM + UT-TI, and BT-DMEM + BT-TI, respectively at 1 $\mu \mathrm{g} / \mathrm{mL}$ compared to the untreated. Further, bone mineralization was significantly increased by $202.34 \%, 200 \%$, and $235.64 \%$ in the UT-DMEM + BT-TI, BT-DMEM + UT-TI, and BT-DMEM + BT-TI, respectively at $10 \mu \mathrm{g} / \mathrm{mL}$ than untreated. Altogether, the Biofield Energy Treated vitamin $\mathrm{D}_{3}$ was significantly improved the bone health parameters and it could be an excellent alternative nutraceutical supplement for vitamin $\mathrm{D}_{3}$ deficiency and fight against various bone-related disorders including osteoporosis, low bone density, osteogenesis imperfecta, Paget's disease, rickets, osteomalacia, deformed bones, autoimmune and inflammatory diseases, stress management and prevention, and anti-aging by improving overall health.
\end{abstract}

Keywords: Osteosarcoma Cells, Biofield Energy Treatment, The Trivedi Effect ${ }^{\circledR}$, Bone Mineralization, Osteoporosis

\section{Introduction}

Vitamin D has multiple effects, which regulate the functions in different organs viz. brain, liver, lungs, heart, kidneys, skeletal, immune and reproductive systems. Moreover, it has significant anti-inflammatory, anti-aging, anti-stress, anti-arthritic, anti-osteoporosis, anti-apoptotic, 
wound healing, anti-cancer, anti-psychotic and anti-fibrotic actions [1]. Vitamin D receptors are widely distributed in most of the body organs viz. brain, liver, heart, lungs, kidney, pancreas, large and small intestines, muscles, reproductive, nervous system, etc. Vitamin D receptors influence cell-tocell communication, normal cell growth, cell differentiation, cell cycling and proliferation, hormonal balance, neurotransmission process, skin health, immune and cardiovascular functions. In any living vertebrates, vitamin D plays an important role in maintaining a healthy skeletal structure and is essential for bone health. Naturally, it is synthesized in the presence of sunlight in the skin [2]. Most foods do not contain any vitamin D, additionally now-a-days due to aging, use of sunscreen, and change of zenith angle of sun the production of vitamin $\mathrm{D}_{3}$ has reduced [3]. Increasing age is not only related to a decrease in bone marrow depression and muscle strength but is also associated with marked changes in the immune and inflammatory responses [4]. Deficiency of vitamin $\mathrm{D}_{3}$ causes metabolic bone diseases like osteomalacia and exacerbate osteoporosis, etc. [5]. The quality of life for menopausal women is one of the most critical health problem in the today world. Metabolic bone disorders like osteoporosis are mainly prevalent in postmenopausal women. Hormonal factors and rapid bone loss in post-menopausal women leads to an increased risk of fractures [6]. Hence, the serum calcium and alkaline phosphatase (ALP) levels in post-menopausal women are the main two vital biochemical markers of bone metabolism. However, bone-specific ALP is the most important marker for osteoblast differentiation [7]. Further, it is generally accepted that an increased calcium intake along with an adequate source of vitamin D is important for maintaining good bone health. Vitamin D also plays an important role in maintaining an adequate level of serum calcium and phosphorus. Therefore, vitamin $\mathrm{D}$ has a great impact in forming and maintaining strong bones [8, 9]. Bone strength depends on the quality, geometry, shape, microarchitecture, turnover, mineral content, and the collagen content. Collagen is the major structural protein responsible for bone calcification. In the aging state, the mechanical properties of the bones become impaired and the bones get fragile, that causes various clinical disorders associated with bone collagen abnormalities and bone fragility, such as osteogenesis imperfecta and osteoporosis [10, 11].

In recent years, several scientific reports and clinical trials have revealed the useful effects of Biofield Energy Treatments, which have shown to enhance immune function in cases of cervical cancer patients via therapeutic touch [12], massage therapy [13], etc. Complementary and Alternative Medicine (CAM) therapies are now rising as preferred models of treatment, among which Biofield Therapy (or Healing Modalities) is one approach that has been reported to have several benefits to enhance physical, mental and emotional human wellness. However, as per the data of 2012 from the National Health Interview Survey (NHIS), which indicated that the highest percentage $(17.7 \%)$ of the Americans used dietary supplements as a complementary health approach as compared with other practices in past years. The National Center of Complementary and Integrative Health $(\mathrm{NCCIH})$ has recognized and accepted Biofield Energy Healing as a CAM health care approach in addition to other therapies, medicines and practices such as natural products, deep breathing, yoga, Tai Chi, Qi Gong, chiropractic/osteopathic manipulation, meditation, massage, special diets, homeopathy, progressive relaxation, guided imagery, acupressure, acupuncture, relaxation techniques, hypnotherapy, healing touch, movement therapy, pilates, rolfing structural integration, mindfulness, Ayurvedic medicine, traditional Chinese herbs and medicines, naturopathy, essential oils, aromatherapy, Reiki, and cranial sacral therapy. Human Biofield Energy has subtle energy that has the capacity to work in an effective manner [14]. CAM therapies have been practiced worldwide with reported clinical benefits in different health disease profiles [15]. This energy can be harnessed and transmitted by the experts into living and non-living things via the process of Biofield Energy Healing. Biofield Energy Treatment (The Trivedi Effect $^{\circledR}$ ) has been published in numerous peer-reviewed science journals with significant outcomes in many scientific fields such as cancer research [16, 17], microbiology [18-20], biotechnology [21, 22], pharmaceutical science [23-26], agricultural science [27-29], materials science [30-32], nutraceuticals [33, 34], skin health [35, 36], human health and wellness.

Based on the literature information and importance of vitamin $\mathrm{D}_{3}$ on bone health, the authors sought to evaluate the impact of the Biofield Energy Treatment (The Trivedi Effect $^{\mathbb{B}}$ ) on the test samples (vitamin $\mathrm{D}_{3}$ and DMEM medium) for bone health activity with respect to the assessment of different bone health parameters like ALP, collagen content, and bone mineralization using standard assays in MG-63 cells.

\section{Materials and Methods}

\subsection{Chemicals and Reagents}

Antibiotic solution (penicillin-streptomycin) was procured from HiMedia, India, while 3-(4, 5-dimethyl-2-thiazolyl)-2, 5-diphenyl-2H-tetrazolium) (MTT), Direct Red 80, and ethylene diamine tetra acetic acid (EDTA) were purchased from Sigma, USA. Fetal bovine serum (FBS) and Dulbecco's Modified Eagle's Medium (DMEM) were purchased from Life Technology, USA. Rutin hydrate was purchased from TCI, Japan, while vitamin $\mathrm{D}_{3}$ (denoted as test item) and Lascorbic acid were obtained from Sigma-Aldrich, USA. All the other chemicals used in this experiment were analytical grade procured from India.

\subsection{Cell Culture}

The human bone osteosarcoma (MG-63) cell line was used as test system, maintained under the DMEM growth medium for routine culture and supplemented with 10\% FBS. Growth conditions were maintained as $37^{\circ} \mathrm{C}, 5 \% \mathrm{CO}_{2}$ and $95 \%$ 
humidity and subcultured by trypsinisation followed by splitting the cell suspension into fresh flasks and supplementing with fresh cell growth medium. Three days before the start of the experiment (i.e., day -3), the growth medium of near-confluent cells was replaced with fresh phenol-free DMEM, supplemented with 10\% charcoal dextran stripped FBS (CD-FBS) and 1\% penicillin-streptomycin [37].

\subsection{Experimental Design}

The experimental groups consisted of cells in baseline control (untreated cells), vehicle control groups $(0.05 \%$ DMSO with Biofield Energy Treated and untreated DMEM), a positive control group (rutin hydrate) and experimental test groups. Experimental test groups included the combination of the Biofield Energy Treated and untreated vitamin $\mathrm{D}_{3}$ /DMEM. It consisted of four major treatment groups on specified cells with UT-DMEM + UT-Test item, UT-DMEM + Biofield Energy Treated test item (BT-Test item), BTDMEM + UT-Test item, and BT-DMEM + BT-Test item.

\subsection{Consciousness Energy Healing Treatment Strategies}

The test item (vitamin $\mathrm{D}_{3}$ ) and DMEM were divided into two parts. One part each of the test item and DMEM were treated with the Biofield Energy (also known as The Trivedi Effect $^{\circledR}$ ) and coded as the Biofield Energy Treated items, while the second part did not receive any sort of treatment and was defined as the untreated samples. This Biofield Energy Healing Treatment was provided by Haddon Norman Salt, who participated in this study and performed the Biofield Energy Treatment remotely for $\sim 5$ minutes. Haddon Norman Saltwas remotely located in the USA, while the test samples were located in the research laboratory of Dabur Research Foundation, New Delhi, India. The Biofield Energy Treatment was administered for 5 minutes through the healer's unique Energy Transmission process remotely to the test samples under laboratory conditions. Biofield Energy Healer's in this study, never visited the laboratory in person, nor had any contact with the test item and medium. Further, the control group was treated with a sham healer for comparative purposes. The sham healer did not have any knowledge about the Biofield Energy Treatment. After that, the Biofield Energy Treated and untreated samples were kept in similar sealed conditions for experimental study.

\subsection{Determination of Non-Cytotoxic Concentration}

The cell viability assay was performed using MTT assay in MG-63 cell line. The cells were counted and plated in a 96 well plates at the density corresponding to $5 \mathrm{X} 10^{3}$ to $10 \mathrm{X}$ $10^{3}$ cells/well/180 $\mu \mathrm{L}$ of cell growth medium. The above cells were incubated overnight under growth conditions and allowed for cell recovery and exponential growth, then they were subjected to serum stripping or starvation. The cells were treated with the test item, DMEM, and the positive control. The untreated cells were served as baseline control. The cells in the above plate (s) were incubated for a time point ranging from 24 to 72 hours in $\mathrm{CO}_{2}$ incubator at $37^{\circ} \mathrm{C}$,
$5 \% \mathrm{CO}_{2}$ and $95 \%$ humidity. After incubation, the plates were taken out and $20 \mu \mathrm{L}$ of $5 \mathrm{mg} / \mathrm{mL}$ of MTT solution was added to all the wells followed by an additional incubation for 3 hours at $37^{\circ} \mathrm{C}$. The supernatant was aspirated and $150 \mu \mathrm{L}$ of DMSO was added to each well to dissolve formazan crystals. The absorbance of each well was read at $540 \mathrm{~nm}$ using a Synergy HT micro plate reader, BioTek, USA. The percentage cytotoxicity at each tested concentration of the test substance was calculated using the following Equation 1:

$$
\% \text { Cytotoxicity }=\{(1-\mathrm{X}) / \mathrm{R}\} * 100
$$

Where, $\mathrm{X}=$ Absorbance of treated cells; $\mathrm{R}=$ Absorbance of untreated cells

The percentage cell viability corresponding to each treatment was then be obtained using the following Equation 2:

$$
\% \text { Cell Viability }=100-\% \text { Cytotoxicity }
$$

The concentrations exhibiting $\geq 70 \%$ Cell viability was considered as non-cytotoxic [38].

\subsection{Assessment of Alkaline Phosphatase (ALP) Activity}

The cells were counted using an hemocytometer and plated in a 24-well plate at the density corresponding to $1 \times 10^{4}$ cells/well in phenol free DMEM supplemented with $10 \%$ CD-FBS. After the respective treatments, the cells in the above plate were incubated for 48 hours in $\mathrm{CO}_{2}$ incubator at $37^{\circ} \mathrm{C}, 5 \% \quad \mathrm{CO}_{2}$ and $95 \%$ humidity. After 48 hours of incubation, the plate was taken out and processed for the measurement of ALP enzyme activity. The cells were washed with 1X PBS and lysed by freeze thaw method i.e., incubation at $-80^{\circ} \mathrm{C}$ for 20 minutes followed by incubation at $37^{\circ} \mathrm{C}$ for 10 minutes. To the lysed cells, $50 \mu \mathrm{L}$ of substrate solution i.e., $5 \mathrm{mM}$ of $p$-nitrophenyl phosphate ( $p$ NPP) in $1 \mathrm{M}$ diethanolamine and $0.24 \mathrm{mM}$ magnesium chloride $\left(\mathrm{MgCl}_{2}\right)$ solution ( $\mathrm{pH}$ 10.4) was added to all the wells followed by incubation for 1 hour at $37^{\circ} \mathrm{C}$. The absorbance of the above solution was read at $405 \mathrm{~nm}$ using Synergy HT micro plate reader (Biotek, USA). The absorbance values obtained were normalized with substrate blank ( $p$ NPP solution alone) absorbance values. The percentage increase in ALP enzyme activity with respect to the untreated cells (baseline group) was calculated using Equation 3:

$$
\% \text { Increase in ALP }=\{(\mathrm{X}-\mathrm{R}) / \mathrm{R}\} * 100
$$

Where, $\mathrm{X}=$ Absorbance of cells corresponding to positive control and test groups

$\mathrm{R}=$ Absorbance of cells corresponding to baseline group (untreated cells)

\subsection{Assessment of Collagen Synthesis}

The MG-63 cells were counted using an hemocytometer and plated in 24-well plate at the density corresponding to 10 $\mathrm{x} 10^{3}$ cells/well in phenol free DMEM supplemented with $10 \%$ CD-FBS. Following the respective treatments, the cells 
in the above plate were incubated for 48 hours in $\mathrm{CO}_{2}$ incubator at $37^{\circ} \mathrm{C}, 5 \% \mathrm{CO}_{2}$ and $95 \%$ humidity. After 48 hours of incubation, the plate were taken out and the amount of collagen accumulated in MG-63 cells corresponding to each treatment was measured by Direct Sirius red dye binding assay. In brief, the cell layers were washed with PBS and fixed in Bouin's solution (5\% acetic acid, 9\% formaldehyde and $0.9 \%$ picric acid) for 1 hour at room temperature (RT). After 1 hour of incubation, the above wells were washed with milliQ water and air dried. The cells were then stained with Sirius red dye solution for 1 hour at RT followed by washing in $0.01 \mathrm{~N} \mathrm{HCl}$ to remove unbound dye. The collagen dye complex obtained in the above step was dissolved in $0.1 \mathrm{~N} \mathrm{NaOH}$ and absorbance was read at $540 \mathrm{~nm}$ using Biotek Synergy HT micro plate reader. The level of collagen was extrapolated using standard curve obtained from purified Calf Collagen Bornstein and Traub Type I (Sigma Type III). The percentage increase in collagen level with respect to the untreated cells (baseline group) was calculated using Equation 4:

$$
\% \text { Increase in collagen levels }=\{(\mathrm{X}-\mathrm{R}) / \mathrm{R}\} * 100
$$

Where, $\mathrm{X}=$ Collagen levels in cells corresponding to positive control and test groups

$\mathrm{R}=$ Collagen levels in cells corresponding to baseline group (untreated cells)

\subsection{Assessment of Bone Mineralization by Alizarin Red $S$ Staining}

The MG-63 cells were counted using an hemocytometer and plated in 24-well plate at the density corresponding to $10 \times 10^{3}$ cells/well in phenol free DMEM supplemented with $10 \% \mathrm{CD}$ FBS. Following the respective treatments, the cells in the above plate were incubated for 48 hours in $\mathrm{CO}_{2}$ incubator at $37^{\circ} \mathrm{C}, 5 \% \mathrm{CO}_{2}$ and $95 \%$ humidity to allow cell recovery and exponential growth. After overnight incubation, the above cells were subjected to serum stripping for 24 hours. The cells were then treated with non-cytotoxic concentrations of the test samples and positive control. Following 3-7 days of incubation with the test samples and positive control, the plates were taken out, cell layers processed further by staining with Alizarin Red S dye. The cells were fixed in 70\% ethanol for 1 hour, after which Alizarin Red solution (40 $\mu \mathrm{m}$; $\mathrm{pH} 4.2)$ was added to the samples for 20 minutes with shaking. The cells were washed with distilled water to remove unbound dye. For quantitative analysis by absorbance evaluation, nodules were solubilized with $10 \%$ cetylpyridinium chloride for 15 minutes with shaking. Absorbance was measured at $562 \mathrm{~nm}$ using Biotek Synergy HT micro plate reader. The percentage increase in bone mineralization with respect to the untreated cells (baseline group) was calculated using the following Equation 5:

$$
\% \text { Increase }=\{(\mathrm{X}-\mathrm{R}) / \mathrm{R}\} * 100
$$

Where, $\mathrm{X}=$ Absorbance in cells corresponding to positive control or test groups; $\mathrm{R}=$ Absorbance in cells corresponding to baseline (untreated) group.

\subsection{Statistical Analysis}

All the values were represented as percentage of the respective parameters. For statistical analysis Sigma-Plot (version 11.0) was used as a statistical tool. Statistically significant values were set at the level of $p \leq 0.05$.

\section{Results and Discussion}

\subsection{MTT Assay}

The results of the MTT cell viability assay of the Biofield Energy Treated vitamin $\mathrm{D}_{3}$ and DMEM in MG-63 cells are shown in Figure 1. The data showed that the test samples in combination found as nontoxic and safe (as evidence of cell viability approximately greater than $79 \%$ ) across all the tested concentrations upto $50 \mu \mathrm{g} / \mathrm{mL}$. Hence, the same concentrations were used for the evaluation of alkaline phosphatase (ALP) activity, collagen synthesis, and bone mineralization in MG-63 cells.

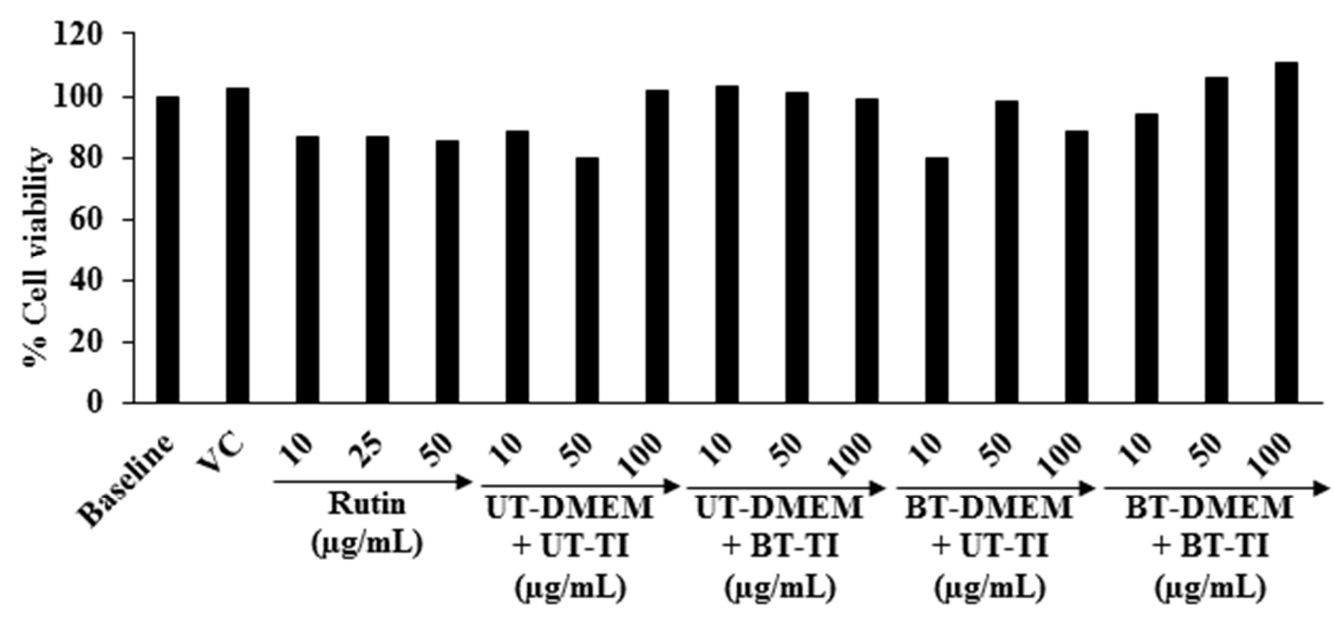

Figure 1. The effect of the test items (vitamin $D_{3}$ and DMEM medium) on cell viability in MG-63 cells after 72 hours of treatment. VC: Vehicle control (0.05\% DMSO); UT: Untreated; BT: Biofield Energy Treated; Test item: TI. 


\subsection{Alkaline Phosphatase (ALP) Activity}

The effect of the test items on ALP activity in MG-63 cells is shown in Figure 2. The vehicle control group showed 1.9\% increased level of ALP activity as compared to the untreated cells group. The ALP activity was significantly increased by $34.31 \%, 51.47 \%$, and $189.39 \%$ in the positive control (rutin) group in a dose-dependent manner at the concentration of $0.01,0.1$, and $1 \mu \mathrm{g} / \mathrm{mL}$, respectively compared to the untreated cells group. The level of ALP was significantly increased by $73.24 \%$ and $85.41 \%$ in the UT-DMEM + BTTest TI and BT-DMEM + BT-TI, respectively at $10 \mu \mathrm{g} / \mathrm{mL}$ compared to the UT-DMEM + UT-TI group. Further, ALP level was significantly elevated by $76.71 \%$ in the BT-DMEM
+ UT-TI group at $0.1 \mu \mathrm{g} / \mathrm{mL}$ compared to the untreated (Figure 2). Deficiency of vitamin D (osteomalacia) causes an increase in bone resorption [39]. Moreover, defective bone remodeling also due to deficiency of vitamin $\mathrm{D}$ that leads to metabolic bone disorders like osteomalacia. For the diagnosis of osteomalacia or rickets, serum ALP activity play a coseffective and sensitive marker [40, 41]. Overall, the Consciousness Energy Treated (The Trivedi Effect ${ }^{\circledR}$ ) vitamin D3 showed an improved synthesis of ALP in the human osteosarcoma cells with respect to the untreated item items group, which might be advantageous to maintain a healthy skeletal structure for the patients suffering from various bone-related disorders.

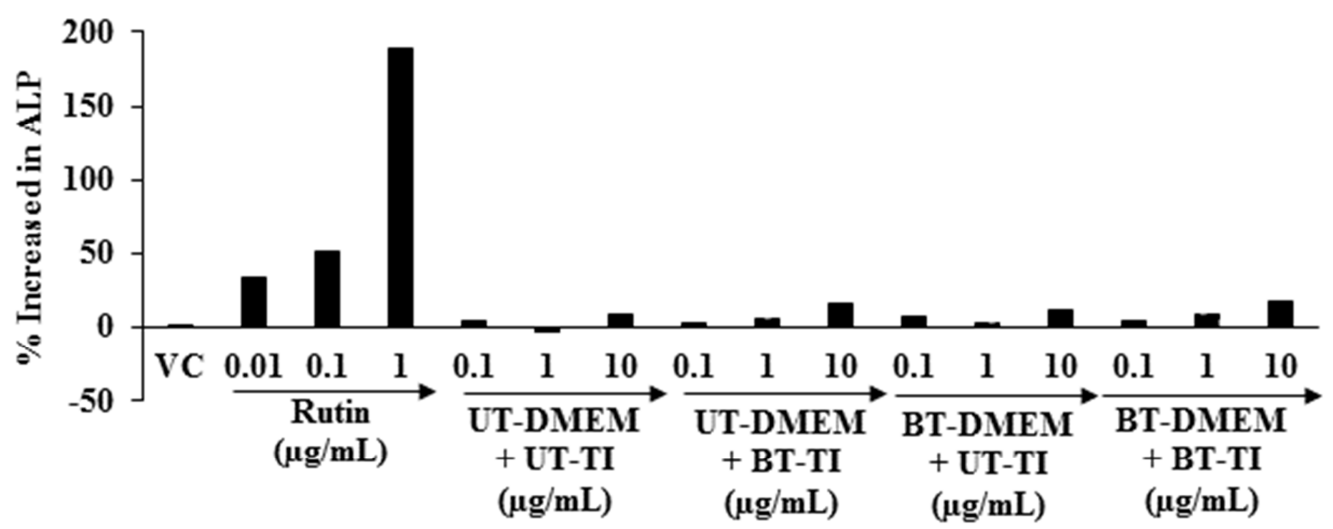

Figure 2. The effect of the test items (vitamin D3 and DMEM medium) on alkaline phosphatase enzyme activity was assessed in human bone osteosarcoma cell after treatment with the Biofield Energy Treated test samples. VC: Vehicle control (0.05\% DMSO), UT: Untreated; BT: Biofield Energy Treated; TI: Test item.

\subsection{Assessment of Collagen Activity}

The effect of the test items on the collagen activity in MG63 cells is shown in Figure 3. Vehicle control group showed $5.6 \%$ increased level of collagen as compared to the untreated cells group. The level of collagen synthesis was significantly increased by $17.76 \%, 28.27 \%$, and $46.50 \%$ at $0.001,0.01$, and $0.1 \mu \mathrm{g} / \mathrm{mL}$, respectively in the positive control group compared to the untreated cells group. The collagen synthesis was significantly increased by $8.75 \%$, $76.31 \%$, and $15.47 \%$ in the UT-DMEM + BT-Test item, BTDMEM + UT-Test item, and BT-DMEM + BT-Test item groups, respectively at $10 \mu \mathrm{g} / \mathrm{mL}$ compared to the UTDMEM + UT-Test item group. Moreover, the collagen level was significantly increased by $77 \%, 113.53 \%$, and $98.00 \%$ in the UT-DMEM + BT-Test item, BT-DMEM + UT-Test item, and BT-DMEM + BT-Test item groups, respectively at 50 $\mu \mathrm{g} / \mathrm{mL}$ compared to the UT-DMEM + UT-Test item group. Additionally, at $100 \mu \mathrm{g} / \mathrm{mL}$ the level of collagen was also significantly increased by $128.05 \%, 10.56 \%$, and $132.10 \%$ in the UT-DMEM + BT-Test item, BT-DMEM + UT-Test item, and BT-DMEM + BT-Test item groups, respectively with respect to the UT-DMEM + UT-Test item group (Figure 3).

Several investigations have observed that vitamin D metabolites directly influence the differentiation and maturation of chondrocytes in calcifying cartilage [42]. Hypovitaminosis D is an important public health problem. The extracellular matrix especially connective tissue with its collagen, plays an important role in the maintenance of bone structure. The turnover of the bone matrix is influenced by collagen synthesis and degrading metalloprotease enzymes increase with the mechanical loading [43]. Overall, the Consciousness Energy Treated vitamin $\mathrm{D}_{3}$ had significantly improved the synthesis of collagen fibers in the human osteosarcoma cells with respect to all the treatment groups. Hence, it is assumed that The Trivedi Effect ${ }^{\circledR}$ has the significant potential to improve the bone health in various skeletal disorders. 


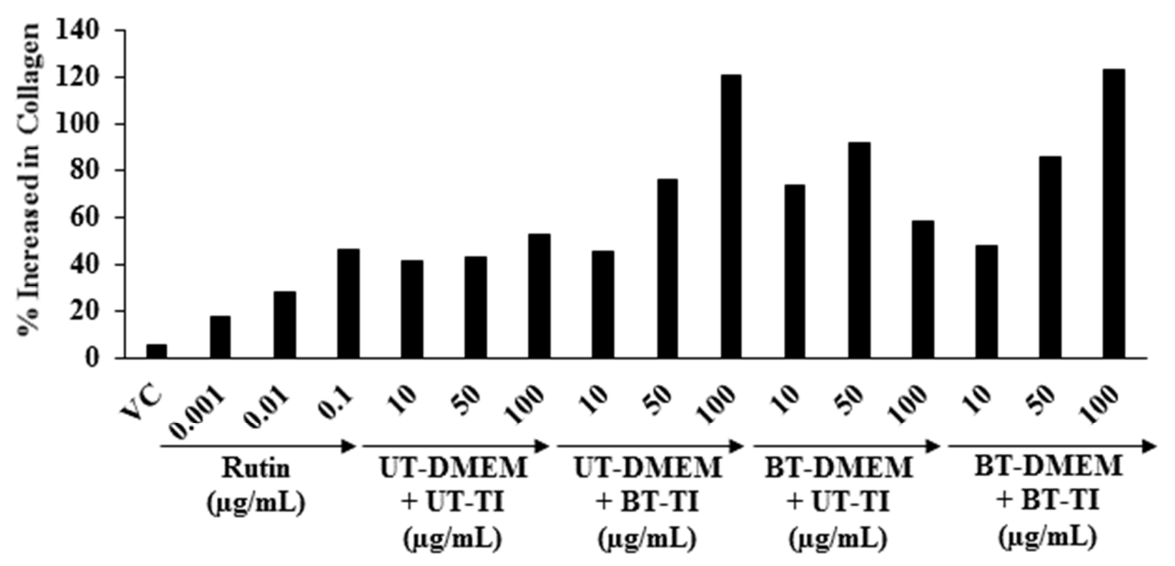

Figure 3. The effect of the test items (vitamin D3 and DMEM medium) on collagen activity in MG-63 cells. VC: Vehicle control (0.05\% DMSO), UT: Untreated; BT: Biofield Energy Treated, TI: Test item.

\subsection{Assessment of Bone Mineralization by Alizarin Red $S$ (ARS) Staining}

The bone mineralization is the primary requirement for the growth and development of overall health. Alteration of bone mineralization leads to a variety of medical anomalies [44]. Overall, the bone mineralization is dependent on a tight local balance between extracellular levels of inorganic phosphate (Pi) and inorganic pyrophosphate (PPi) which is regulated by different ALP enzymes [45]. The effect of the test items on mineralization of bone in MG-63 cells is shown in Figure 4. The vehicle control (VC) group showed $9.8 \%$ increased bone mineralization as compared to the untreated cells (normal control) group. The percentage of bone mineralization was significantly increased in a concentration-dependent manner by $12.38 \%, 33.66 \%$, and $56.93 \%$ at $0.01,0.1$, and $1 \mu \mathrm{g} / \mathrm{mL}$, respectively in the positive control group compared to the untreated cells group. The percent of bone mineralization was remarkably increased by $82.43 \%, 158.97 \%$, and $52.95 \%$ in the UT-DMEM + BT-Test item, BT-DMEM + UT-Test item, and BT-DMEM + BT-Test item group at $0.1 \mu \mathrm{g} / \mathrm{mL}$ compared to the UT-DMEM + UT-Test item group. Further, a noticeably increased percentage of bone mineralization by $118.41 \%, 197.42 \%$, and $116.94 \%$ in the UT-DMEM + BTTest item, BT-DMEM + UT-Test item, and BT-DMEM + BT-Test item groups, respectively was found at $1 \mu \mathrm{g} / \mathrm{mL}$ with respect to the UT-DMEM + UT-Test item group. In addition, the data showed a significant increase of bone mineralization by $202.34 \%, 200 \%$, and $235.64 \%$ in the UT-DMEM + BTTest item, BT-DMEM + UT-Test item, and BT-DMEM + BT-Test item groups, respectively than the UT-DMEM + UT-Test item group (Figure 4) at $10 \mu \mathrm{g} / \mathrm{mL}$. Thus, based on the above findings, it is postulated that the Biofield Energy Treated vitamin $D_{3}$ showed a remarkable improvement of bone mineralization content assessed by in vitro in the human osteosarcoma cells (MG-63) with respect to the all others treatment groups.

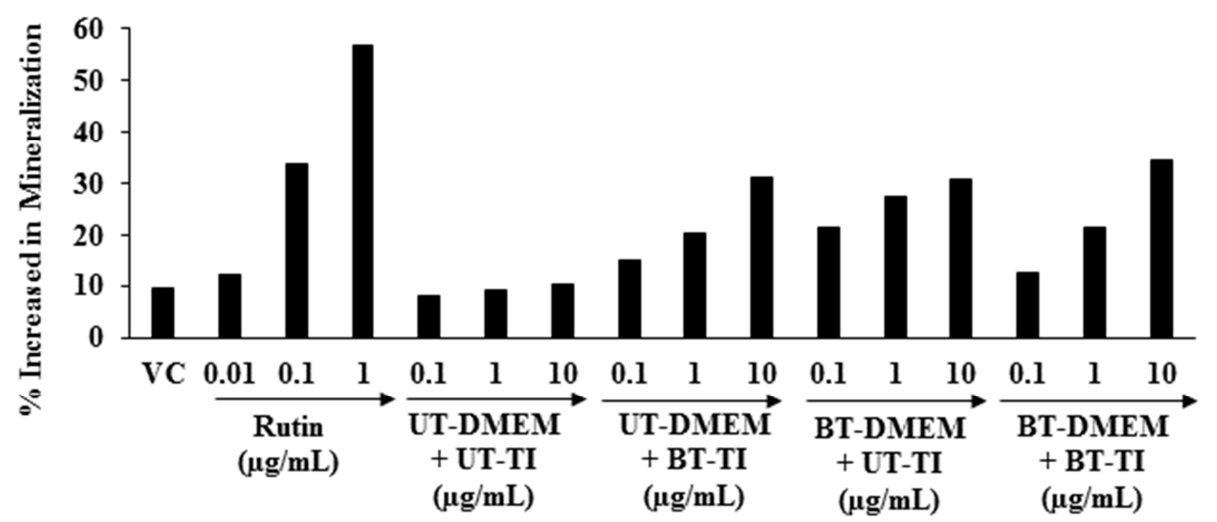

Figure 4. The effect of the test items (vitamin D3 and DMEM medium) on bone mineralization activity in human bone osteosarcoma cells. VC: Vehicle control (0.05\% DMSO), UT: Untreated; BT: Biofield Energy Treated, TI: Test item.

\section{Conclusions}

The MTT cell viability assay data showed greater than $79 \%$ cells were viable, which indicated that the test samples were safe and nontoxic in all the tested concentrations. The level of ALP was significantly increased by $73.24 \%$ and $85.41 \%$ in the
UT-DMEM + BT-Test TI and BT-DMEM + BT-TI, respectively at $10 \mu \mathrm{g} / \mathrm{mL}$ compared to the UT-DMEM + UTTI group. Further, ALP level was significantly elevated by $76.71 \%$ in the BT-DMEM + UT-TI group at $0.1 \mu \mathrm{g} / \mathrm{mL}$ compared to the untreated. Collagen was significantly increased by $128.05 \%$ and $132.10 \%$ in the UT-DMEM + BTTest item and BT-DMEM + BT-Test item group at $100 \mu \mathrm{g} / \mathrm{mL}$, 
respectively; while increased by $76.31 \%$ in the BT-DMEM + UT-TI at $10 \mu \mathrm{g} / \mathrm{mL}$ compared to the untreated group. Further, the level of collagen was significantly increased by $77 \%$, $113.53 \%$, and $98.00 \%$ in the UT-DMEM + BT-Test item, BTDMEM + UT-Test item, and BT-DMEM + BT-Test item groups, respectively at $50 \mu \mathrm{g} / \mathrm{mL}$ compared to the UT-DMEM + UT-Test item group. Besides, the percent of bone mineralization was distinctly increased by $82.43 \%, 158.97 \%$, and $52.95 \%$ in the UT-DMEM + BT-Test item, BT-DMEM + UT-Test item, and BT-DMEM + BT-Test item groups, respectively at $0.1 \mu \mathrm{g} / \mathrm{mL}$ compared to the untreated group. Additionally, the percent of bone mineralization was distinctly increased by $118.41 \%, 197.42 \%$, and $116.94 \%$ in the UTDMEM + BT-Test item, BT-DMEM + UT-Test item, and BT$\mathrm{DMEM}+\mathrm{BT}-\mathrm{Test}$ item, respectively at $1 \mu \mathrm{g} / \mathrm{mL}$ compared to the untreated. Further, the level of percent of bone mineralization was significantly increased by $202.34 \%, 200 \%$, and $235.64 \%$ in the UT-DMEM + BT-Test item, BT-DMEM + UT-Test item, and BT-DMEM + BT-Test item, respectively at $10 \mu \mathrm{g} / \mathrm{mL}$ compared to the untreated. Altogether, the Biofield Energy Treated test samples (The Trivedi Effect ${ }^{\mathbb{B}}$ ) demonstrated a significant impact on bone health parameters. Therefore, the Consciousness Energy Healing based vitamin $\mathrm{D}_{3}$ might be suitable for the development of an alternative and more effective supplement for vitamin $\mathrm{D}_{3}$ deficiency, which could be useful for the management of various bone related disorders viz. low bone density and osteoporosis, osteogenesis imperfecta, Paget's disease of bone, rickets, osteomalacia, bone and joint pain, bone fractures, deformed bones, osteoma, chondrodystrophia fetalis, etc. Besides, it can also be utilized in organ transplants (for example kidney transplants, liver transplants and heart transplants), various autoimmune disorders such as Lupus, Addison Disease, Celiac Disease (gluten-sensitive enteropathy), Dermatomyositis, Graves' Disease, Hashimoto Thyroiditis, Multiple Sclerosis, Myasthenia Gravis, Pernicious Anemia, Aplastic Anemia, Reactive Arthritis, Rheumatoid Arthritis, Sjogren Syndrome, Systemic Lupus Erythematosus, Type 1 Diabetes, Alopecia Areata, Crohn's Disease, Fibromyalgia, Vitiligo, Psoriasis, Scleroderma, Chronic Fatigue Syndrome and Vasculitis, as well as inflammatory disorders such as Asthma, Ulcerative Colitis, Alzheimer's Disease, Atherosclerosis, Dermatitis, Diverticulitis, Hepatitis, Irritable Bowel Syndrome, inflammatory diseases, anti-inflammatory, anti-stress, antiarthritic, anti-osteoporosis, anti-apoptotic, wound healing, anticancer, anti-psychotic and anti-fibrotic actions stress management and prevention, and anti-aging by improving overall health, Parkinson's Disease and stress etc. to modulate the immune system by improving overall health.

\section{Abbreviations}

MG-63: Human Bone Osteosarcoma Cells, ALP: Alkaline phosphatase, CAM: Complementary and alternative medicine, NHIS: National Health Interview Survey, NCCIH: National Center of Complementary and Integrative Health, DMEM: Dulbecco's modified eagle's medium, FBS: Fetal bovine serum,
ATCC: American type culture collection, UT: Untreated, BT: Biofield Energy Treated, ECM: Extracellular matrix

\section{Acknowledgements}

Authors are grateful to Dabur Research Foundation, Trivedi Global, Inc., Trivedi Science, Trivedi Testimonials and Trivedi Master Wellness for their support throughout the work.

\section{References}

[1] Holick MF (2004) Sunlight and vitamin D for bone health and prevention of autoimmune diseases cancers, and cardiovascular disease. Am J Clin Nut 80: 1678S-1688S.

[2] Holick MF (1996) Vitamin D and bone health. J Nutr 126: 1159S-1164S.

[3] Matsuoka LY, Ide L, Wortsman J, MacLaughlin JA, Holick MF (1987) Sunscreens suppress vitamin $D_{3}$ synthesis. J Clin Endocrinol Metab 64: 1165-1168.

[4] Barnes MS, Robson JP, Bonham MP, Strain J, Wallace J (2006) Vitamin D: Status, supplementation and immunodulation. Cur Nut Food Sci 2: 315-336.

[5] Laird E, Ward M, McSorley E, Strain JJ, Wallace J (2010) Vitamin D and bone health; Potential mechanisms. Nutrients 2: 693-724.

[6] Bhattarai T, Bhattacharya K, Chaudhuri P, Sengupta P (2014) Correlation of common biochemical markers for bone turnover, serum calcium, and alkaline phosphatase in postmenopausal women. Malays J Med Sci 21: 58-61.

[7] Iba K, Takada J, Yamashita T (2004) The serum level of bone-specific alkaline phosphatase activity is associated with aortic calcification in osteoporosis patients. J Bone Miner Metab 22: 594-596.

[8] Holick MF, Garabedian M (2006) Vitamin D: Photobiology, metabolism, mechanism of action, and clinical applications. Primer on the metabolic bone diseases and disorders of mineral metabolism. Edited by: Favus MJ, Washington, DC.

[9] DeLuca HF (2004) Overview of general physiologic features and functions of vitamin D. Am J Clin Nutr 80: 1689S-1696S.

[10] Viguet-Carrin S, Garnero P, Delmas PD (2006) The role of collagen in bone strength. Osteoporos Int 17: 319-336.

[11] Sroga GE, Vashishth D (2012) Effects of bone matrix proteins on fracture and fragility in osteoporosis. Curr Osteoporos Rep 10: 141-150.

[12] Lutgendorf SK, Mullen-Houser E, Russell D, Degeest K, Jacobson G, Hart L, Bender D, Anderson B, Buekers TE, Goodheart MJ, Antoni MH, Sood AK, Lubaroff DM (2010) Preservation of immune function in cervical cancer patients during chemoradiation using a novel integrative approach. Brain Behav and Immun 24: 1231-1240.

[13] Ironson G, Field T, Scafidi F, Hashimoto M, Kumar M, Kumar A, Price A, Goncalves A, Burman I, Tetenman C, Patarca R, Fletcher MA (1996) Massage therapy is associated with enhancement of the immune system's cytotoxic capacity. Int J Neurosci 84: 205-217. 
[14] Jain S, Hammerschlag R, Mills P, Cohen L, Krieger R, Vieten C, Lutgendorf S (2015) Clinical studies of biofield therapies: Summary, methodological challenges, and recommendations. Glob Adv Health Med 4: 58-66.

[15] Rubik B (2002) The biofield hypothesis: Its biophysical basis and role in medicine. J Altern Complement Med 8: 703-717.

[16] Trivedi MK, Patil S, Shettigar H, Mondal SC, Jana S (2015) The potential impact of biofield treatment on human brain tumor cells: A time-lapse video microscopy. J Integr Oncol 4: 141.

[17] Trivedi MK, Patil S, Shettigar H, Gangwar M, Jana S (2015) In vitro evaluation of biofield treatment on cancer biomarkers involved in endometrial and prostate cancer cell lines. J Cancer Sci Ther 7: 253-257.

[18] Trivedi MK, Patil S, Shettigar H, Bairwa K, Jana S (2015) Phenotypic and biotypic characterization of Klebsiella oxytoca: An impact of biofield treatment. J Microb Biochem Technol 7: 203-206.

[19] Trivedi MK, Patil S, Shettigar H, Mondal SC, Jana S (2015) Evaluation of biofield modality on viral load of hepatitis B and C Viruses. J Antivir Antiretrovir 7: 083-088.

[20] Trivedi MK, Branton A, Trivedi D, Nayak G, Mondal SC, Jana S (2015) Antimicrobial sensitivity, biochemical characteristics and biotyping of Staphylococcus saprophyticus: An impact of biofield energy treatment. J Women's Health Care 4: 271.

[21] Nayak G, Altekar N (2015) Effect of biofield treatment on plant growth and adaptation. J Environ Health Sci 1: 1-9.

[22] Trivedi MK, Branton A, Trivedi D, Nayak G, Charan S, Jana S (2015) Phenotyping and 16S rDNA analysis after biofield treatment on Citrobacter braakii: A urinary pathogen. J Clin Med Genom 3: 129.

[23] Branton A, Jana S (2017) The influence of energy of consciousness healing treatment on low bioavailable resveratrol in male Sprague Dawley rats. International Journal of Clinical and Developmental Anatomy 3: 9-15.

[24] Branton A, Jana S (2017) The use of novel and unique biofield energy healing treatment for the improvement of poorly bioavailable compound, berberine in male Sprague Dawley rats. American Journal of Clinical and Experimental Medicine 5: 138-144.

[25] Branton A, Jana S (2017) Effect of The biofield energy healing treatment on the pharmacokinetics of 25hydroxyvitamin D3 [25 $(\mathrm{OH}) \mathrm{D} 3]$ in rats after a single oral dose of vitamin D3. American Journal of Pharmacology and Phytotherapy 2: 11-18.

[26] Trivedi MK, Branton A, Trivedi D, Nayak G, Gangwar M, Jana S (2016) Molecular analysis of biofield treated eggplant and watermelon crops. Adv Crop Sci Tech 4: 208.

[27] Trivedi MK, Branton A, Trivedi D, Nayak G, Mondal SC, Jana S (2015) Morphological characterization, quality, yield and DNA fingerprinting of biofield energy treated alphonso mango (Mangifera indica L.). Journal of Food and Nutrition Sciences 3: 245-250.

[28] Trivedi MK, Branton A, Trivedi D, Nayak G, Mondal SC, Jana S (2015) Evaluation of plant growth, yield and yield attributes of biofield energy treated mustard (Brassica juncea) and chick pea (Cicer arietinum) seeds. Agriculture, Forestry and Fisheries 4: 291-295.

[29] Trivedi MK, Branton A, Trivedi D, Nayak G, Mondal SC, Jana S (2015) Evaluation of plant growth regulator, immunity and DNA fingerprinting of biofield energy treated mustard seeds (Brassica juncea). Agriculture, Forestry and Fisheries 4: 269-274.

[30] Trivedi MK, Tallapragada RM, Branton A, Trivedi D, Nayak G, Jana S (2015) Characterization of physical and structural properties of aluminum carbide powder: Impact of biofield treatment. J Aeronaut Aerospace Eng 4: 142.

[31] Trivedi MK, Nayak G, Patil S, Tallapragada RM, Latiyal O, Jana S (2015) Impact of biofield treatment on atomic and structural characteristics of barium titanate powder. Ind Eng Manage 4: 166.

[32] Trivedi MK, Patil S, Nayak G, Jana S, Latiyal O (2015) Influence of biofield treatment on physical, structural and spectral properties of boron nitride. J Material Sci Eng 4: 181.

[33] Trivedi MK, Nayak G, Patil S, Tallapragada RM, Jana S, Mishra RK (2015) Bio-field treatment: An effective strategy to improve the quality of beef extract and meat infusion powder. J Nutr Food Sci 5: 389.

[34] Trivedi MK, Tallapragada RM, Branton A, Trivedi D, Nayak G, Mishra RK, Jana S (2015) Biofield treatment: A potential strategy for modification of physical and thermal properties of gluten hydrolysate and ipomoea macroelements. J Nutr Food Sci 5: 414.

[35] Kinney JP, Trivedi MK, Branton A, Trivedi D, Nayak G, Mondal SC, Jana S (2017) Overall skin health potential of the biofield energy healing based herbomineral formulation using various skin parameters. American Journal of Life Sciences 5: 65-74.

[36] Singh J, Trivedi MK, Branton A, Trivedi D, Nayak G, Gangwar M, Jana S (2017) Consciousness energy healing treatment based herbomineral formulation: A safe and effective approach for skin health. American Journal of Pharmacology and Phytotherapy 2: 1-10.

[37] Czekanska EM, Stoddart MJ, Richards RG, Hayes JS (2012) In search of an osteoblast cell model for in vitro research. Eur Cells Mater 24: 1-17.

[38] Biological evaluation of medical devices - Part 5: Tests for in vitro cytotoxicity (ISO 10993-5:2009), I. S. EN ISO, 109935:20093.

[39] Need AG (2006) Bone resorption markers in vitamin D insufficiency. Clinica Chimica Acta 368 48-52.

[40] Taylor JA, Richter M, Done S, Feldman KW (2010) The utility of alkaline phosphatase measurement as a screening test for rickets in breast-fed infants and toddlers: A study from the puget sound pediatric research network. Clin Pediatr (Phila) 49: $1103-1110$.

[41] Sahay M, Sahay R (2012) Rickets-vitamin D deficiency and dependency. Indian J Endocrinol Metab 16: 164-176.

[42] Schwartz Z, Schlader DL, Ramirez V, Kennedy MB, Boyan BD (1989) Effects of vitamin D metabolites on collagen production and cell proliferation of growth zone and resting zone cartilage cells in vitro. J Bone Miner Res 4: $199-207$ 
[43] Kjaer M, Magnusson P, Krogsgaard M, Boysen Møller J, Olesen J, Heinemeier K, Hansen M, Haraldsson B, Koskinen S, Esmarck B, Langberg H (2006) Extracellular matrix adaptation of tendon and skeletal muscle to exercise. J Anat 208: $445-450$

[44] Boonrungsiman S, Gentleman E, Carzaniga R, Evansa ND, McComba DW, Portera AE, Stevensa MM (2012) The role of intracellular calcium phosphate in osteoblast-mediated bone apatite formation. Proceedings of the National Academy of Sciences of the United States of America 109: 14170-14175.

[45] Donatti TL, Koch VH, Takayama L, Pereira RM (2011) Effects of glucocorticoids on growth and bone mineralization. J Pediatr (Rio J) 87: 4-12. 